\title{
APPROACHES TO PREDICTING THE EFFICACY AND SAFETY OF AMLODIPINE IN PATIENTS WITH ARTERIAL HYPERTENSION OF I-II DEGREE BASED ON PHARMACOGENETIC STUDIES
}

\author{
Sychev D. A. ${ }^{1}$, Shih N. V. ${ }^{2}$, Morozova T. E. ${ }^{2}$, Ismagilov A. D. ${ }^{2}$,
} Shih E. V. ${ }^{2}$, Mirzaev K. B. ${ }^{1}$, Atakulova S. S. ${ }^{2}$

${ }^{1}$ Russian Medical Academy of Continuous Professional Education, Moscow, Russian Federation

2 I. M. Sechenov First Moscow State Medical University (Sechenov University), Moscow, Russian Federation

\section{ПОАХОАЫ К ПРОГНОЗИРОВАНИЮ ЭФФЕКТИВНОСТИ И БЕЗОПАСНОСТИ АМАОАИПИНА У ПАЦИЕНТОВ С АРТЕРИААЬНОЙ ГИПЕРТЕНЗИЕЙ І-ІІ СТЕПЕНИ НА ОСНОВЕ ФАРМАКОГЕНЕТИЧЕСКИХ ИССАЕАОВАНИЙ}

\author{
А. А. Сычёв ${ }^{1}$, Н. В. Ших ${ }^{2}$, Т. Е. Морозова ${ }^{2}$, А. А. Исмагилов ${ }^{2}$, \\ Е. В. Ших ${ }^{2}$, К. Б. Мирзаев ${ }^{1}$, С. Ш. Атакулова ${ }^{2}$
}
1 Российская меАицинская акаАемия непрерывного профессионального образования, Москва, Российская ФеАерация
2 Первый Московский госуАарственный меАицинский университет им. И. М. Сеченова (Сеченовский Университет), Москва, Российская Фелерация

At the study conducted of increase the efficacy and safety of therapy in patients with arterial hypertension $(\mathrm{AH})$ of I-II degree by personalizing the choice of amlodipine dosage regimen based on genotyping by ABCB1, CYP3A5, and phenotyping by CYP3A4. Clinical and pharmacogenetic study of amlodipine was conducted with 100 patients with arterial hypertension I-II degree between the ages of 42 to $58,(m-45 \%, f-55 \%)$. The «SNP-Screen» set («Sintol», Russia) was used to determine the polymorphism of the CYP3A5 gene. The metabolic activity of the CYP3A4 isoenzyme was determined by high-performance liquid chromatography (HPLC). The metabolic activity of CYP3A4 was calculated from the 6-beta-hydroxycortisol/ cortisol ratio in the morning urine. Our study showed associations between the CYP3A5 gene from the polymorphic marker A6986G and the safety profile of amlodipine, and the lack of significant influence of the course of amlodipine on CYP3A4 activity. In the AG genotype of the CYP3A5 gene, higher antihypertensive efficacy is associated with a higher risk of developing ADR, whereas in the GG genotype - lower efficacy and less risk of developing ADR. The activity of CYP3A4 does not change with the background use of amlodipine $(p=0.06)$. The obtained pharmacogenetic data make it possible to propose an algorithm for personalized choice of the dosage regimen of amlodipine for patients with an AH I-II degree.

Keywords: pharmacogenetics, personalized medicine, gene polymorphisms, arterial hypertension, amlodipine

Проводилось изучение возможностей повышения эффективности и безопасности терапии у пациентов с артериальной гипертензией (АГ) І-ІІ степени путем персонализации выбора режима дозирования амлодипина на основе генотипирования по маркерам АВСВ1, СҮРЗА5 и фенотипирования СҮРЗА4. В клиническое и фармакогенетическое исследование амлодипина было включено 100 пациентов с артериальной гипертензией I-ІІ степени в возрасте от 42 до 58 лет (м - 45 \%, ж - 55 \%). Для определения полиморфизма гена СҮРЗА5 был использован набор «SNP-Screen» («Синтол», Россия). Метаболическая активность изофермента СYP3А4 определялась С помощью высокоэффективной жидкостной хроматографии. Метаболическая активность СҮРЗА4 рассчитывалась по соотношению 6-бета-гидроксикортизол/кортизол в утренней моче. По результатам исследования были обнаружены взаимосвязь между полиморфизмом A6986G гена CYP3A5 и профилем безопасности амлодипина, а также отсутствие влияния приема амлодипина на активность CYP3A4. Вариант AG гена CYP3A5 ассоциирован с более выраженным антигипертензивным эффектом амлодипина и высоким риском развития неблагоприятных побочных реакций. В то время как при генотипе GG эффективность препарата и риск развития неблагоприятных побочных реакций ниже. Активность СҮРЗА4 статистически значимо не изменялась при приеме амлодипина $(p=0,06)$. Полученные фармакогенетические данные позволяют предложить алгоритм персонализированного выбора режима дозирования амлодипина для пациентов с АГ I-ІІ степени.

Ключевые слова: фармакогенетика, персонализированная медицина, полиморфизмы генов, артериальная гипертензия, амлодипин 
For citation: Sychev D. A., Shih N. V., Morozova T. E., Ismagilov A. D., Shih E. V., Mirzaev K. B., Atakulova S. S. APPROACHES TO PREDICTING THE EFFICACY AND SAFETY OF AMLODIPINE IN PATIENTS WITH ARTERIAL HYPERTENSION OF I-II DEGREE BASED ON PHARMACOGENETIC STUDIES. Medical News of North Caucasus. 2019;14(3):435-438. DOI - https://doi.org/10.14300/mnnc.2019.14105

Для цитирования: Сычёв Д. А., Ших Н. В., Морозова Т. Е., Исмагилов А. Д., Ших Е. В., Мирзаев К. Б., Атакулова С. Ш. ПОДХОДЫ К ПРОГНОЗИРОВАНИЮ ЭФФЕКТИВНОСТИ И БЕЗОПАСНОСТИ АМЛОДИПИНА У ПАЦИЕНТОВ С АРТЕРИАЛЬНОЙ ГИПЕРТЕНЗИЕЙ І-ІІ СТЕПЕНИ НА ОСНОВЕ ФАРМАКОГЕНЕТИЧЕСКИХ ИССЛЕДОВАНИЙ. МЕДИцинский вестник Северного Кавказа. 2019;14(3):435-438. DOI - https://doi.org/10.14300/mnnc.2019.14105

ABPM - ambulatory blood pressure monitoring

ACEIs - angiotensin-converting enzyme inhibitors

ADR - adverse drug reaction

$\mathrm{AH}$ - arterial hypertension
BP - blood pressure

CCB - calcium channel blockers

CVD - cardiovascular diseases
0 ne of the risk factors for the development of cardiovascular diseases (CVD) and their complications is arterial hypertension (AH). At present, diuretics, beta-blockers, angiotensin II receptor blockers (ARBs), angiotensin-converting enzyme (ACE inhibitors), calcium channel blockers (CCB) are the agents of choice for long-term pharmacotherapy of hypertension. Despite the wide choice of medicines, control over the level of blood pressure (BP) often remains unsatisfactory and the number of people with uncontrolled BP increases every year.

Among the antihypertensive drugs, calcium channel blockers (CCB) are widely used at present. They occupy one of the leading places in the world in the frequency of prescribing to patients with cardiovascular diseases and sales in the pharmaceutical market both among cardiological means and drugs in general. Amlodipine is one of the most studied and used in the clinical practice of dihydropyridine CCB. It is a representative of the third generation of drugs of this group, which is on the list of vital and essential medicines for more than ten years [1, 2], and in the mandatory medical and economic standard of medical assistance to patients with $\mathrm{AH}$ [http://mkb-10.com].

The evidence base of amlodipine indicating high efficacy is extensive, and it includes large-scale clinical studies such as ALLHAT [3], VALUE [4], ACCOMPLISH [5], ASCOT-BPLA, etc. However, along with undeniable antihypertensive efficacy, there are adverse drug reactions (ADR). Thus, about a quarter of patients stop taking amlodipine due to the development of their ADR, the most frequent of which are peripheral edema due to vasodilation. Also, when the dihydropyridine CCB is used, reddening of the face and upper limbs may develop, which is associated with reflex activation of the sympathoadrenal system in response to systemic vasodilation.

The reasons for the lack of $\mathrm{AH}$ monitoring and the development of ADR are varied. Factors such as age, the presence of concomitant diseases, and polypharmacy are essential in this regard. However, considerable attention has recently been given to the study of the genetic characteristics of patients, which can largely determine the pharmacological response to a particular drug. The value of genetic factors can reach $50 \%$ in individual sensitivity to the drug $[6,7]$.

It is known that a significant role in the metabolism of amlodipine is given to $\mathrm{P}$-glycoprotein, which is encoded by the ABCB1 gene. P-glycoprotein is a protein of the cell membranes, through which the efflux of medicinal substances from cells is carried out. As a result of the studies, it was shown that in patients with the TT genotype, theamount of P-glycoprotein on the cytoplasmic membrane was reduced by the C3435T polymorphic marker of the $\mathrm{ABCB} 1 \mathrm{gene}$, and the activity of the $\mathrm{P}$-glycoprotein is also likely to decrease, therefore, this group of patients has a slower «clearance» of drugs-substrates of P-glycoprotein from the endotheliocyte into the blood.

Earlier, we conducted a study that demonstrated the connection between different allelic variants of the ABCB1 gene with the efficacy of amlodipine. It was shown that patients with the TT genotype had a higher antihypertensive effect in combination with the lowest incidence of adverse reactions, while among the group of CC genotype carriers antihypertensive effect was smaller, and rate of adverse effects was the highest [8]. Thus, the data of this study supplement and expand data on pharmacogenetics of amlodipine, obtained earlier by other authors, which seem ambiguous and contradictory. Therefore, it was shown in several studies that there are no statistically significant differences in the pharmacokinetic and pharmacodynamic parameters of amlodipine in patients with different genetic polymorphisms of the ABCB1 gene and the clinical efficacy of amlodipine in patients with different genotypes is comparable $[9,10]$.

Along with the ABCB1, some other genetic polymorphisms such as CYP3A4/5 can also influence the metabolism of this medication. This determines the appropriateness of studying the pharmacogenetic features of amlodipine. The introduction into clinical practice of an individualized approach to patients, based on an assessment of both the phenotypic and genetic characteristics of patients will increase the effectiveness and safety of ongoing pharmacotherapy.

The data of clinical studies on pharmacogenetics of amlodipine available in both domestic and foreign literature are not numerous and do not allow us to single out convincing correlations between the indices of amlodipine efficacy and the parameters of its safety by the genetic characteristics of patients.

In this regard, the aim of our study was to explore the possibilities of increasing the efficacy and safety of therapy in patients with $\mathrm{AH} \mathrm{I-II} \mathrm{degree} \mathrm{by} \mathrm{personalizing}$ the choice of amlodipine dosage regimen based on genotyping by $A B C B 1, C Y P 3 A 5$, and phenotyping by CYP3A4.

Material and Methods. The Ethics committee of I. M. Sechenov First Moscow State Medical University approved the study (protocol № 02-15 of 18.02.15). The clinical part of the study, including all clinical and instrumental studies were conducted based on the University Clinical Hospital № 1 of Sechenov University. Genotyping by CYP3A5 and phenotyping of CYP3A4 was carried out in the department of molecular biological studies of the Russian Medical Academy of Continuing Postgraduate Education.

Inclusion criteria: men and women over the age of 18 with $\mathrm{AH} \mathrm{I-II} \mathrm{degree,} \mathrm{who} \mathrm{signed} \mathrm{informed} \mathrm{consent} \mathrm{to}$ participate in the study. 
Criteria for non-inclusion in the study: $\mathrm{AH}$ III degree and uncontrolled hypertension, unstable angina, acute myocardial infarction, myocardial revascularization operations or acute cerebral circulation impairment less than 6 months prior to enrollment, arterial hypotension, CHF III-IV $\mathrm{FC}$ in decompensation stage, hemodynamically significant stenosis of heart valves, hypertrophic cardiomyopathy, exacerbation of chronic inflammatory or other diseases requiring additional prescription or correction of drug therapy and other conditions that can affect the results of the study.

The study included $100 \mathrm{AH}$ patients who meet the inclusion and non-inclusion criteria at the age of 42 to 58 years (mean age is $48.8 \pm 8.31$ years), men - 45 (45\%), women - 55 (55\%), AH I degree was in 75 patients (75\%), AH II degree in 25 (25\%).

The control of efficacy and safety of the therapy was carried out using general clinical methods of examination (analysis of complaints, collection of anamnesis according to the duration of hypertension, risk factors, concomitant diseases, physical examination, anthropometric measurement), ECG registration, BP registration according to office measurement and ambulatory BP monitoring (ABPM), genotyping by the A6986G polymorphic marker of the CYP3A5 gene, and phenotyping by CYP3A4

ABPM was carried out using BR-102 portable recorders («Shiller», Switzerland) for 24 hours with the monitor installed between 9 a.m. and 11 a.m.

For genotyping, venous blood was used in VACUETTE $®$ vacuum test tubes (Greiner Bio-One, Austria) with Ethylenediaminetetraacetic acid (EDTA). The carrier of the polymorphic markers of the CYP3A5 gene was detected by real-time polymerase chain reaction (Real-Time PCR) on the CFX384 TouchRealTime PCR DetectionSystem (Bio-Rad Laboratories, Inc., USA) and Applied Biosystems Step One TM (Life Technologies, USA). To determine the polymorphisms of the CYP3A5 gene, the «SNP-Screen» set (CJSC «Sintol», Russia) was used.

The metabolic activity of the CYP3A4 isoenzyme was determined by high-performance liquid chromatography (HPLC) on a high-performance liquid chromatograph Agilent G1978B Multimode Soursefor 6410 Triple Quade LC/MS (Agilent Technologies, Inc., USA). The metabolic activity of CYP3A4 was calculated from the 6-betahydroxycortisol/cortisol ratio in the morning urine.

Statistical processing of results. The normality of the distribution was verified using the Kolmogorov-Smirnov test (K-S test). To assess the reliability of differences in quantitative indicators, a one-way analysis of variance (ANOVA) was used, and the 14 Mann - Whitney or Kruskal - Wallis test in the case of an abnormal distribution. To establish the differences between the categorical indicators, Pearson's chi-squared test $\left(\chi^{2}\right)$ was applied. Fisher's exact test was used to verify the observance of the Hardy-Weinberg equilibrium. Differences were considered significant at $p<0.05$.

Results and Discussion. The distribution of the examined patients of the CYP3A5 genotypes and A6986G polymorphic marker was as follows: the AG genotype occurred in 9 patients ( $9 \%$ ), GG genotype in 91 patients (91\%), AA genotype - 0 patients (0\%). Patients with AG and GG genotypes did not differ in their initial clinical and demographic characteristics between themselves and the study group of patients as a whole.

The analysis of antihypertensive efficacy of amlodipine showed that good efficacy in patients with the AG genotype was $78 \%$, with the GG genotype was $65 \%$. An increase in the dose to $10 \mathrm{mg}$ was required for two patients with the AG genotype and 32 patients with the GG genotype, which was $22 \%$ and $35 \%$ in the percentage ratio, respectively (Fig. 1).

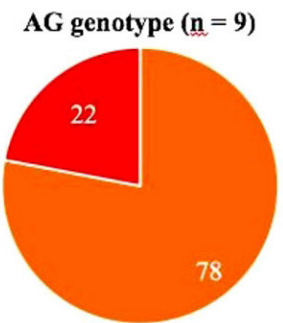

- Excellent, abs. (\%)

- Good, abs. (\%)

- Satisfactory, abs. (\%)

Need for increased dose is $22 \%$

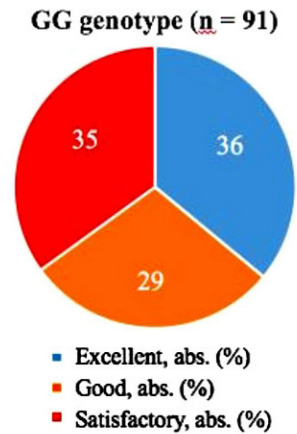

Need for increased dose is $35 \%$
Fig. 1. Antihypertensive efficacy of amlodipine in patients with $\mathrm{AH} \mathrm{I-I} \mathrm{degree} \mathrm{with} \mathrm{different} \mathrm{genotypes} \mathrm{from} \mathrm{the} \mathrm{A6986G}$ polymorphic marker of the CYP3A5 gene

According to the office BP measurement, there was a statistically significant decrease in patients with the GG genotype in systolic BP-8.38 \pm 2.4 (AG-6.71 \pm 3.22 D, \%) $(p=0.04)$ as well as diastolic BP-9.11 \pm 4.08 (AG-7.39 $\pm 3.18 \mathrm{D}, \%)$ ( $\mathrm{p} A \mathrm{G}-\mathrm{GG}=0.03$ ). According to the ABPM, a somewhat higher degree of decrease in the mean daily, average daily, and average values of SBP and DBP was detected in patients with the AG genotype.

In general, when analyzing the intergroup differences by the Mann-Whitney method between the AG and GG genotypes, there were no statistically significant differences in the frequency of achievement of the target $B P$ values and the severity of the antihypertensive effect.

At the same time, there were differences in the tolerability of amlodipine between the AG and GG genotypes. Thus, ADR in the form of edema of the lower extremities was predominantly observed in 4 out of 9 patients (44\%) with the AG genotype. In patients with the GG genotype the absolute number of ADR, mostly in the form of skin flushing, was higher $(n=10)$, but in percentage ratio was only $11 \%$ (reliability of $A G$ intergroup differences vs. $G G p=0.04$ ). In patients with the GG genotype, there was no evidence of ADR in the form of edema, and there was no ADR in the form of hyperemia in patients with the AG genotype.

With a sensitivity of $28.8 \%$ and a specificity of $92.7 \%$, ADR may be predicted in patients with the GG genotype in the case of increasing the amlodipine dose from 5 to $10 \mathrm{mg}$.

A comprehensive analysis of the summary efficacy and tolerability of amlodipine in patients with $\mathrm{AH} \mathrm{I-II} \mathrm{de-}$ gree depending on the genotype by the A6986G polymorphic marker of the CYP3A5 gene showed that the higher antihypertensive efficacy is combined with a higher risk of developing ADR in the AG genotype by the A6986G polymorphic marker of the CYP3A5 gene, whereas in GG genotype is lower antihypertensive efficacy and less risk of ADR developing.

The CYP3A4 activity evaluated by the non-invasive method for the $6 \beta$-hydroxycortisol/cortisol test in urine does not change in the background of amlodipine course use: the ratio of cortisol concentration to the concentration of 6-hydroxycortisol in urine before treatment with amlodipine was $1.03 \pm 1.02$, in the background of amlodipine course use was $0.94 \pm 1.01(p=0.06)$.

There was no statistically significant correlation between the value of the 6-beta-hydroxycortisol/cortisol ratio and the dynamics of SBP, DBP according to the results of an office BP measurement and 24-hour monitoring in patients with $\mathrm{AH} \mathrm{I-II} \mathrm{degree} \mathrm{who} \mathrm{received} \mathrm{amlodipine} \mathrm{at}$ doses of 5 and $10 \mathrm{mg}$ per day for 12 weeks. 
The separate analysis of CYP3A4 activity in terms of 6-beta-hydroxy cortisol/cortisol did not reveal significant differences in the ratio of before and after amlodipine use in patients with AH I-II degree with different CYP3A5 genotypes (Table)

$\begin{gathered}\text { Indicators of CYP3A4 activity (estimated by the ratio } \\
\text { of cortisol and urinary } 6 \beta \text {-hydroxycortisol) in patients } \\
\text { with AH I-II degree with different genotypes of CYP3A5 } \\
\text { against the amlodipine course dose }\end{gathered}$
\begin{tabular}{|l|l|l|}
\hline \multirow{2}{*}{$\begin{array}{c}\text { Geno- } \\
\text { types }\end{array}$} & The metabolic ratio (6-B-hydroxycortisol/cortisol) \\
\cline { 2 - 3 } & Before & 12 weeks \\
\hline GG & 1.04 & 1 \\
\hline P & \multicolumn{2}{|c|}{ CYP3A5 genotype } \\
\hline AG & 0.94 & 0.6 \\
\hline p & \multicolumn{2}{|c|}{0.65} \\
\hline
\end{tabular}

A comprehensive analysis of the overall efficacy and tolerability of amlodipine in patients with different genotypes from the A6986G polymorphic marker of the CYP3A5 gene showed differences in the parameters of tolerance. Thus, in the AG genotype for the A6986G polymorphic marker of the CYP3A5 gene, higher antihypertensive efficacy is combined with a higher risk of ADR developing, whereas there are lower antihypertensive efficacy and less chance of ADR developing in the GG genotype.

The revealed associations between the carriage of various CYP3A5 genotypes on the A6986G polymorphic marker, the parameters of antihypertensive efficacy and the safety profile of amlodipine, in combination with the results of our previous study of $A B C B 1$ genetic polymorphism suggest the algorithm for personalized choice of amlodipine dosage regimen for patients with AH I-II degree (Fig. 2).

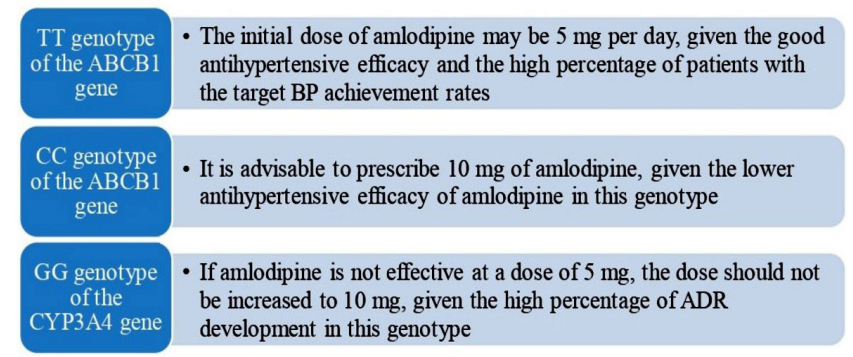

Fig. 2. Amlodipine dosing algorithm based on pharmacogenetic testing

Conclusions. Thus, taking into account the data obtained, we can assume that in the future, we can expect the use of pharmacogenetic testing for ABCB1 and CYP3A5 to predict the profile of efficacy and safety before prescribing amlodipine in patients with $\mathrm{AH} \mathrm{I-II}$ degree. In patients with AH I-II degree with TT genotype by the ABCB1 polymorphic marker C3435T gene can be expected to have a more favorable profile of efficacy/ safety in comparison with the CC genotype. Genotype GG by the CYP3A5 genetic polymorphism is associated with a high percentage of adverse drug reactions. This demonstrates the potential of the study of the different genotypes on the ABCB1 and CYP3A5 polymorphic markers precisely from a personalized approach to pharmacotherapy, including the use of amlodipine in persons of the Caucasian race.

\section{Disclosures:}

The authors declare no conflict of interest.

References

1. Federal Guideline to Medication administration. Publication № XIIII. 2012:157-168.

2. Resolution of the Government of the Russian Federation № 2343-r of 29 December. 2005.

3. The ALLHAT Officers and coordinators for the ALLHAT collaborative research group. Major cardiovascular events in hypertensive patients randomized to doxazosin vs. chlorthalidone. The Antihypertensive and Lipid-Lowering Treatment to Prevent Heart Attack Trial (ALLHAT). JAMA. 2000; 283: 1967-75. https://doi:10.1001/jama.288.23.2981

4. Julius S., Kjeldsen S. E., Weber M. [et al.] Outcomes in hypertensive patients at high cardiovascular risk treated with regimens based on valsartan or amlodipine. The VALUE randomized trial. Lancet. 2004;363(9426):2022-31. https://doi.org/10.1007/s12325-008-0042-x

5. Bakris G. L., Sarafidis P. A., Weir M. R. [et al.] Renal outcomes with different fixed-dose combination therapies in patients with hypertension at high risk for cardiovascular events (ACCOMPLISH): a prespecified secondary analysis of a Randomized controlled trial. Lancet. 2010;375(9721): 1173-81. https://doi.org/10.1016/S0140-6736(09)62100-0
6. Diagnosis and treatment of arterial hypertension. Clinical recommendations. Kardiologicheskiy Vestnik. 2015;10(1): 30-31.

7. Chazova I. Ye., Zhernakova Yu. V., Oshchepkova Ye. V. [et al.] Prevalence of risk factors for cardiovascular diseases in the Russian population of patients with arterial hypertension. Kardiologiia. 2014;10:4-12.

8. Sychev D., Shikh N., Morozova T., Grishina E., Ryzhikova K. [et al.] Effects of $A B C B 1$ rs 1045642 polymorphisms on the efficacy and safety of amlodipine therapy in Caucasian patients with stage I-II hypertension. Pharmacogenomics Pers. Med. 2018:11:157-165.

https://doi.org/10.2147/PGPM S158401

9. Guo C., Pei Q. I., Tan H. [et al.] Effects of genetic factors on the pharmacokinetics and pharmacodynamics of amlodipine in primary hypertensive patients. Biomed. Rep. 2015;3(2):195-200. https://doi.org/10.3892/br.2014.395

10. Huang Y., Wen G., Lu Y. [et al.] CYP3A4* $1 G$ and CYP3A5*3 genetic polymorphisms alter the antihypertensive efficacy of amlodipine in patients with hypertension following renal transplantation. Int. J. Clin. Pharmacol. Ther. 2017;55(2):109-111. http://doi.org/10.5414/CP202559

\section{About authors:}

Sychev Dmitry Alexeevich, MD, PhD, Professor, Corresponding Member of the Russian Academy of Sciences, Head of the Department of clinical pharmacology and therapy; tel.: +74992547824, e-mail: dmitry.alex.sychev@gmail.com

Shih Nadezhda Valeryevna, PhD, Assistant of the Department of general medical practice;

tel.: +79162153931; e-mail: nadya-shikh@yandex.ru

Morozova Tatiana Evgenyevna, PhD, Professor, Head of the Department of general medical practice;

tel.: +74992487544; e-mail: temorozova@gmail.com

Ismagilov Artur Damirovich, PhD student of the Department of medico-social examination, emergency and outpatient therapy

tel.: +79177757752; e-mail: artur.ismagilov88@gmail.com

Shih Evgenia Valeryevna, MD, PhD, Professor, Head of the Department of clinical pharmacology and propaedeutics of internal medicine;

tel.: +74992488892; e-mail: chih@mail.ru

Mirzaev Karin Badavievich, MD, PhD, Head of the Department of personalized medicine of Scientific Institute of molecular and personalized medicine; tel.: +79637827442; e-mail: karin05doc@yandex.ru

Atakulova Sarvinoz Sharafidinovna, student; tel.: +79256126825; e-mail: sarvinoz.atakulova@gmail.com 